Ekonomia - Wroclaw Economic Review 26/1 (2020)

Acta Universitatis Wratislaviensis

No 3991

https://doi.org/10.19195/2658-1310.26.1.9

Daria Pielucha

ORCID: 0000-0001-7825-4041

Uniwersytet Wrocławski

dariapielucha96@gmail.com

\title{
Analiza krótko- i długookresowych związków pomiędzy giełdami azjatyckimi a rynkiem europejskim i amerykańskim
}

\author{
Artykuł nadesłany: 20.04.2020; artykuł zaakceptowany: 30.04.2020 \\ Kody klasyfikacji JEL: C51, C58, G15
}

Keywords: Asian markets, distributed lag models, co-integration

\begin{abstract}
Analysis of the short and long-term relationship between Asian exchanges and the European and American markets

The aim of the article is to assess the relations between the Chinese and Japanese stock exchanges in relation to the American and European markets represented by the German market and to assess the impact of price fluctuations of the S\&P500 and DAX indices on Asian stock exchange indices. In the study, the ADF test was used, according to which the degree of integration of the studied processes was determined and an appropriate class of distributed lag models and error correction was selected for the assessment of short- and long-term dependencies. The results of the conducted analysis clearly indicate that Asian exchanges are linked to both the American and German markets, but only in the case of index pairs NI225-DAX and SSEC-SP500 was the co-integration of processes confirmed, i.e. their joint pursuit of a long-term balance. In the case of the remaining pairs, co-integration has not been confirmed, which means that there is a spurious correlation and therefore, a correct analysis of the mutual relations in these cases allows only short-term relationships to be detected. The results of the article may be helpful in choosing an investment strategy on Asian exchanges adapted to its time horizon.
\end{abstract}

\section{Wstęp}

Przez ostatnie piętnaście lat można było zaobserwować intensywny wzrost gospodarczy krajów Azji. Doprowadziło to do podwyższonego zainteresowania in- 
westycjami w spółki z tego regionu, a liberalizacja i deregulacja na tych rynkach pozwoliła zwiększyć przepływ zagranicznego kapitału do firm azjatyckich. Giełdy z Azji szybko nabrały dużego znaczenia na tle światowych rynków.

Za najbardziej rozwinięte $\mathrm{z}$ nich uznaje się obecnie rynek Japonii oraz Chin. Choć rynek japoński przeżywał okres bessy po 2008 roku, to zdołał wyjść z kryzysu i obecnie jest największym rynkiem azjatyckim. Firmy istniejące na tym rynku, będące liderami w branżach high-tech, telekomunikacyjnej czy transportowej, są zachętą dla zagranicznych inwestorów, a otwartość rynku, podobnie jak na giełdzie amerykańskiej, ciągle dostarcza firmom japońskim kapitału od pozakrajowych akcjonariuszy. Na rozwój tej giełdy wpływa również stymulująca gospodarkę polityka państwa. Przeniesienie produkcji wielu dóbr lub ich części składowych do Chin doprowadziło do znacznego uzależnienia światowych gospodarek od gospodarki chińskiej, a co za tym idzie do istotnego wzrostu gospodarczego kraju. Rozwój Chin można dostrzec na rynkach finansowych w Szanghaju, Shenzen oraz Hongkongu. Giełda w Szanghaju składająca się w większości z dużych państwowych spółek jest obecnie, za rynkami amerykańskimi i japońskim, największą giełdą na świecie. Rynki chińskie nie są jednak tak szeroko dostępne dla inwestorów zagranicznych jak giełda japońska czy amerykańska. Wyznaczone są dla nich bowiem specjalne akcje klasy B dla spółek notowanych na giełdzie shanghajskiej i w Shenzen oraz akcje klasy H, które dotyczą spółek notowanych na giełdzie w Hongkongu. Większość akcji, które oznaczone są jako klasa A, przysługuje jednak inwestorom krajowym (Giełda w Chinach, 2019).

Rynki azjatyckie zdobyły duże zainteresowanie wśród inwestorów z całego świata, co przyczyniło się do rozwoju powiązań gospodarczych między krajami Azji a resztą globu. Wzrost aktywności przedsiębiorstw na arenie międzynarodowej doprowadził do globalizacji rynków finansowych, co oznacza, że narodowe rynki walutowe, pieniężne czy też kredytowe powiązały się we wspólny globalny rynek finansowy (Domańska-Szaruga, 2009, 62). Na globalizację rynków wpłynęła w dużej mierze liberalizacja i deregulacja, polegające między innymi na takich działaniach, jak zniesienie ograniczeń związanych z bezpośrednimi inwestycjami zagranicznymi, obniżenie podatków dotyczących transakcji międzynarodowych oraz ograniczenie ingerencji państwa w stopy procentowe i kursy walutowe (Domańska-Szaruga, 2009, 67-68). Pozytywnym aspektem globalizacji jest więc rozwój wymiany międzynarodowej, która prowadzi do wzrostu gospodarczego, w krajach biorących w niej udział. Zwiększenie powiązań rynków na świecie wpłynęło na ich intensywne oddziaływanie na siebie, a rozwój technologiczny, który przyspieszył przepływ informacji i ułatwił ich dostępność, przyczynił się do przyspieszenia reakcji inwestorów na rynkach. Rozwój powiązań na giełdach może jednak powodować pewną niestabilność rynków finansowych. Wzrost tych zależności doprowadził to do powstania efektu ,zarażania się” rynków, którego najlepszym przykładem jest kryzys na rynku kredytów hipotecznych z 2008 roku w Stanach Zjednoczonych. Ryzyko inwestycji obecnie często jest więc związane 
ze zmianą sytuacji na innych rynkach. Jest to tak zwane ryzyko systematyczne, przed którym nie można się zabezpieczyć (Ryzyko rynkowe).

Celem niniejszej pracy jest zbadanie zależności między największymi giełdami azjatyckimi a giełdą amerykańską i niemiecką, będącej przykładem giełdy europejskiej. Problem powiązań rynków finansowych podejmowany był wcześniej przez wielu autorów, jednak nie w kontekście rynków azjatyckich. W artykule przy użyciu metod statystyczno-ekonometrycznych dokonano porównania wybranych azjatyckich indeksów giełdowych w stosunku do indeksu amerykańskiego i niemieckiego. Zastosowano klasyczną metodę MNK do estymacji parametrów regresji wielorakiej pozwalającej ocenić, czy pomiędzy indeksami istnieje korelacja, która ma sens związku przyczynowo-skutkowego, czy też jest to korelacja pozorna. Następnie zastosowano test ADF na ustalenie stopnia zintegrowania procesu, co pozwoliło poprawnie zastosować modele o opóźnieniach rozłożonych oraz odpowiednio modeli korekty błędem ECM i tym samym wskazać, które z giełd charakteryzują się związkiem o charakterze krótkookresowym, a które z nich są skointegorwane, czyli istnieje pomiędzy nimi określona długookresowa zależność.

\section{Azjatyckie rynki finansowe}

Rynki Chin i Japonii są — zaraz po giełdach amerykańskich — najważniejszymi rynkami na świecie. Łączny wolumen giełdy w Szanghaju i w Shenzen w maju 2007 roku wynosił więcej niż wolumen wszystkich giełd pozostałych krajów Azji i Australii łącznie. W 2010 roku giełdy chińskie stanowiły już 5\% działalności wszystkich giełd światowych (Lasoń, 2010, 130). Giełda w Hongkongu będącym specjalnym regionem administracyjnym Chin, cechującym się najwyższym stopniem wolności gospodarczej na świecie, w 2018 roku miała największy wolumen spośród giełd azjatyckich (HKEX Fact Book 2018...). Japońska giełda natomiast pod względem kapitalizacji znajduje się tuż za giełdami amerykańskimi. Rynki azjatyckie są kojarzone z innowacyjnymi spółkami z branży technologicznej zajmującymi się między innymi telekomunikacją, elektroniką, farmacją, czy też mają powiązania z branżą transportową. Stoją one w opozycji do giełd europejskich, na których największe spółki należą do branż spożywczej, finansowej czy też odzieżowej. Spółki na rynku japońskim oraz chińskim są główną konkurencją firm amerykańskich, w związku z tym rynki te oddziałują na siebie. Wyścig technologiczny napędza rozwój rynków zarówno azjatyckich, jak i amerykańskich. W ciągu ostatnich dziesięciu lat na indeksach giełd Chin i Japonii można zaobserwować znaczy wzrost. Indeksami reprezentującymi te rynki są:

— indeks japoński Nikkei 225,

— indeks szanghajski Shanghai Composite Index,

— indeks w Hongkongu. 
Pierwszy indeks reprezentujący giełdę w Tokio jest indeksem cenowym, w którego skład wchodzą takie firmy, jak Canon, Mazda, Mitsubishi, Toshiba, Casio, Sony oraz inne światowe marki. Japoński indeks Nikkei 225 maksymalną wartość osiągnął w 1989 roku — wynosiła ona blisko 39 tysięcy. Indeks nie zdołał powrócić do poziomu z końca lat osiemdziesiątych. Wartość indeksu od tego czasu systematycznie spadała aż do roku 2003, gdy najniższa wartość wyniosła blisko 3 tysiące. Kolejne lata były okresem hossy na rynku japońskim $i$ indeks zdołał odbić się do wartości ponad 18 tysięcy, jednak po kryzysie jego wartość osiągnęła swoje minimum w tej dekadzie, wynoszące 7054.98. Po okresie bessy wyniki giełdy stopniowo wzrastały, a pod koniec stycznia 2020 roku ceny kształtowały się na poziomie 23 tysięcy (Dane historyczne: Nikkei 225 - Japan). Obecna dobra kondycja giełdy jest jednak w dużym stopniu zasługą działań rządu, który w momencie dużych spadków na rynku zainwestował w krajowe spółki poprzez fundusze ETF (Rosik, 2019).

Szanghajski indeks Shanghai Composite Index uważany jest za miernik kondycji gospodarki Chin. Do najbardziej znanych spółek wchodzących w skład tego indeksu należą Bank of China, China Petroleum \& Chemical, Air China, China Coal Energy czy też PetroChina (Shanghai Stock Exchange...). W 2007 roku Shanghai Composite Index osiągnął rekordową wartość wynoszącą ponad 6 tysięcy. Okres kryzysu był dla szanghajskiego indeksu wyjątkowo dotkliwy, jego wartość spadła aż o blisko 70\%. W roku 2009 rząd chiński, próbując walczyć ze skutkami załamania gospodarczego, wprowadził pakiet o wartości 650 mld USD, który miał na celu stymulowanie gospodarki przez inwestycje mieszkalne i infrastrukturalne. Działania te spowodowały podwojenie się wartości indeksu w 2009 roku, jednak w kolejnych latach nastąpił stopniowy spadek jego wartości (Schittek, 2014). Indeks szanghajski odbił się znowu w latach 2014-2015 i wzrósł do wartości 5100 w czerwcu 2015 roku. Pod koniec stycznia wynosił blisko 3000 (Dane historyczne: Shanghai Composite Index - China). Ceny na giełdzie szanghajskiej są narażone na spore wahania ze względu na angażowanie się państwa w spółki notowane na giełdzie oraz fakt, że jedynie 7\% akcji należy do drobnych akcjonariuszy chińskich, a około $80 \%$ jest w rękach kilkunastu bardzo bogatych inwestorów (Giełda w Chinach, 2019).

Główny indeks giełdowy giełdy w Hongkongu - Hang Seng Index Indeks — tworzą między innymi takie spółki, jak China Petroleum \& Chemical Corp., PetroChina Co. Ltd., Lenovo Group Limited, Bank of China Limited i Hang Seng Bank Limited (Hong Kong Stock Exchange). Indeks ten jest indeksem cenowym, nieuwzględniającym dywidend i warrantów subskrypcyjnych (Index Methodology For Managing...). Do roku 2018 najwyższa jego wartość wyniosła 30 tysięcy na koniec roku 2007. Wpływ kryzysu z 2008 roku spowodował spadek wartości indeksu do 12 tysięcy na początku 2009 roku. Od tego czasu indeks rósł pomimo kilku mniejszych spadków w 2011 i 2015 aż do początku 2018, kiedy to indeks osiągnął swoje maksimum równe 33 tysięcy. Od stycznia 2018 do początku 2019 
roku indeks spadł o blisko $17 \%$. Na koniec stycznia 2020 utrzymywał się on na poziomie 26000 (Notowania ${ }^{\wedge}$ HSI...).

\section{Modele DL i VECM w analizie procesów niestacjonarnych}

Powszechnie stosowanym modelem do wykrywania związków między zmiennymi są modele regresji wielorakiej postaci:

$$
y_{t}=\alpha_{0}+\sum_{i=1}^{k} \alpha_{i} x_{t i}+\varepsilon_{t}
$$

Parametry modelu szacuje się z wykorzystaniem klasycznej metody najmniejszych kwadratów (KMNK), jednak jej poprawne zastosowanie w przypadku szeregów czasowych wiąże się ze stacjonarnością procesów objętych analizą. Proces jest stacjonarny, gdy spełnia łącznie następujące przesłanki:

- stałość wariancji procesu w czasie,

- stałość wartości oczekiwanej procesu w czasie,

— brak zależności kowariancji zmiennych pochodzących z różnych okresów od czasu (Analiza Szeregów Czasowych, 2009).

W przeciwnym wypadku wyniki zastosowania regresji wielorakiej nie mogą stanowić podstawy wnioskowania o związku przyczynowo-skutkowym. Wynika to $\mathrm{z}$ faktu, iż trwałe tendencje zmian w szeregu czasowym, skutkujące jego niestacjonarnością względem wartości oczekiwanej, stwarzają zagrożenie regresją pozorną. W szczególności można wskazać sytuacje, gdy zmienne niestacjonarne „błądzą wspólnie” w tym sensie, że różnica między nimi jest stacjonarna. Innymi słowy, choć w każdej z nich występuje trend, to trendy te są skorelowane tak, że nie rozbiegną się w czasie. O takich zmiennych mówimy, że są skointegrowane. Regresja pomiędzy takimi zmiennymi ma sens, a jeśli reszty są stacjonarne, to znaczy, że zmienne współewoluują w taki sposób, że różnica między nimi pozostaje stacjonarna. W takich przypadkach zatem testowanie kointegracji ma służyć odróżnianiu regresji pozornej (w której nie ma kointegracji zmiennych) od regresji sensownej wyrażającej związek długofalowy (w której zmienne są skointegrowane). Oznacza to, że ewentualne odwrócenie trendu w jednej zmiennej spotka się z odpowiednim odwróceniem trendu innej zmiennej, tak że różnica pozostanie wciąż stacjonarna. W tym celu przeprowadza się test Dickeya-Fullera pierwiastka jednostkowego, który oparty jest na statystyce testowej postaci (Prenzena, 2016, 111):

$$
D F=\frac{\hat{\delta}}{S(\hat{\delta})}
$$


Gdy wartość bezwzględna statystyki testowej jest większa od wartości krytycznej odczytanej z tablic Dickeya i Fullera, odrzucamy hipotezę zerową na rzecz hipotezy o stacjonarności. W teście DF zatem odrzucenie hipotezy zerowej, w której zakłada się istnienie pierwiastka jednostkowego, na rzecz hipotezy alternatywnej zakładającej stacjonarność procesu pozwala na stwierdzenie, że zmienna jest stacjonarna, czyli jest zintegrowana rzędu 0 , co oznacza się jako I(0). Brak podstaw do odrzucenia hipotezy zerowej oznacza, że badany szereg jest niestacjonarny (ma pierwiastek jednostkowy), jest zatem zintegrowany w stopniu co najmniej 1 i należy kontynuować weryfikację w celu ustalenia stopnia zintegrowania. Wówczas następnym etapem analizy powinno być testowanie integracji pierwszego rzędu, to znaczy należy powtórzyć test DF, używając przyrostów zmiennej zamiast jej poziomów (Prenzena, 2016, 111).

$\mathrm{O}$ zmiennych $\mathrm{X}$ oraz $\mathrm{Y}$ mówimy, że są skointegrowane, jeśli można znaleźć taką ich liniową kombinację, która będzie stacjonarna (Przekota, 2007, 136). Równania takie nazywamy kointegrującymi, wektor parametrów zaś równania — wektorem kointegrującym. Co ważne, kointegracja jest sposobem opisu równowagi długookresowej, co oznacza, że jeżeli zmienne są skointegrowane z wektorem kointegrującym, wówczas zależność można przedstawić za pomocą Mechanizmu Korekty Błędem (ECM):

$$
\Delta y_{t}=\alpha\left(y_{t}-\beta x_{t}\right)+\sum_{i=1}^{p} \gamma_{p} \Delta x_{t-p}+\sum_{i=1}^{p} \theta_{p} \Delta y_{t-p}+\varepsilon_{t}
$$

gdzie proces resztowy $\varepsilon_{t} \sim I(0)$

Model ECM jest próbą połączenia opisu zjawiska długofalowej równowagi (występujące, gdy zmienne są skointegrowane) z krótkookresowymi stanami nierównowagi. W krótkim okresie to odchylenie od równowagi długookresowej, znak parametru informuje o kierunku odchylenia od równowagi długookresowej, a jego wielkość informuje o części odchylenia od równowagi długookresowej korygowanej podczas pierwszego okresu (Przekota, 2007, 113-114).

\section{Wyniki badań empirycznych}

W celu zbadania ryzyka inwestycji na giełdach Chin i Japonii na tle rynków światowych wybrano trzy indeksy azjatyckie: Hang Seng Index, Nikkei 225 oraz Shanghai Composite Index, reprezentujące giełdy w Hongkongu, giełdę japońską oraz giełdę szanghajską, i dwa indeksy światowe: S\&P 500 oraz DAX, reprezentujące rynki amerykański i europejski. Zebrane dane dotyczą tygodniowych cen zamknięcia od 25 lutego 1991 roku do 27 stycznia 2020 roku, czyli od momentu dostępności danych dla wszystkich giełd. By dokonać wstępnej oceny powiązań wybranych indeksów, wzięto pod uwagę wykres ich cen zamknięcia (rysunek1). 


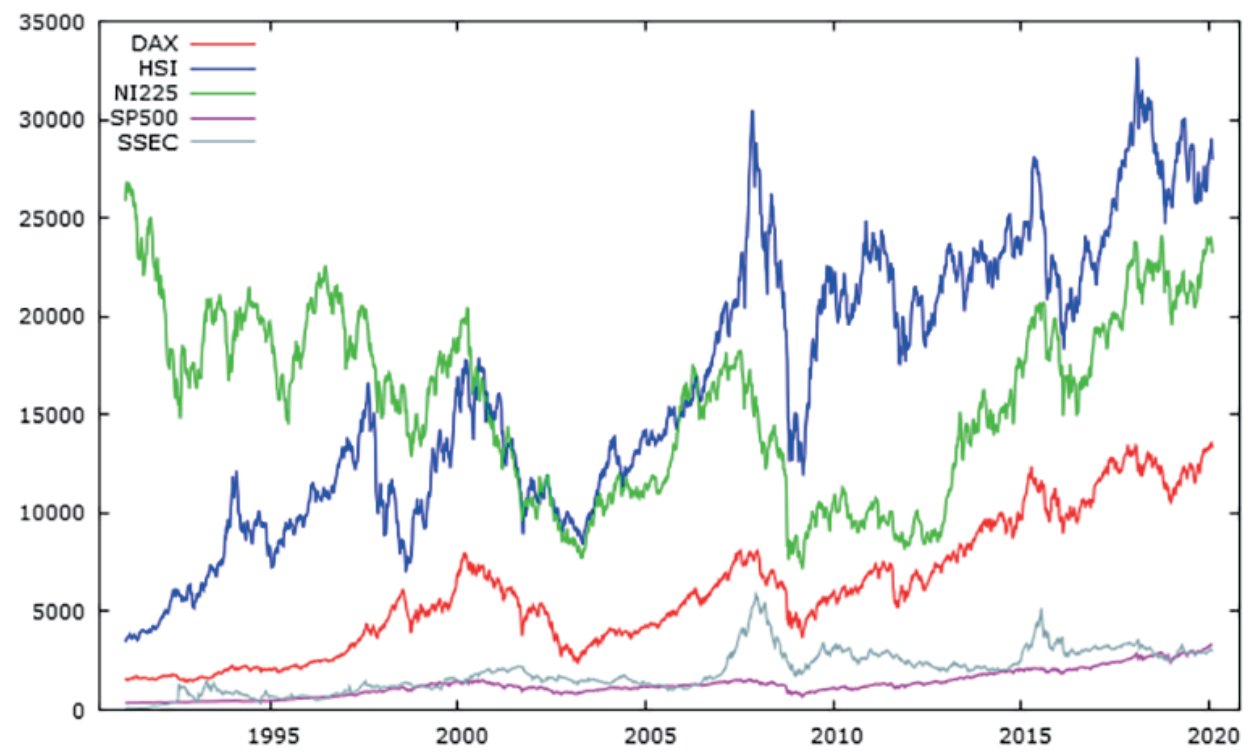

Rysunek 1. Wykres cen zamknięcia indeksów w okresie 25.02.1991-27.01.2020

Źródło: opracowanie własne na podstawie danych z http://www.stooq.pl (dostęp: 15.04.2020).

Na podstawie wykresów kształtowania się cen zamknięcia zaobserwowano, że wszystkie przedstawione procesy indeksów giełdowych są niestacjonarne względem wartości oczekiwanej i wariancji. Zwraca uwagę wyraźna wspólna tendencja dla indeksu giełdy w Hongkongu oraz indeksu niemieckiego, natomiast indeks japoński przyjmuje podobny kierunek ruchu cen do tych dwóch rynków po roku 2000, co świadczyłoby o tym, że można podejrzewać zależność między tymi procesami. Ze względu na niestacjonarność zarówno względem wartości oczekiwanej, jak i wariancji wykorzystano logarytmiczne stopy zwrotu, które są sposobem detrendyzacji oraz wygaszania wariancji, które zilustrowano na rysunku 2.

Zilustrowane dane potwierdzają, że indeksy giełdowe są stacjonarne względem przyrostów, a tym samym stwarzają zagrożenie regresją pozorną. W szczególności zagrożenie regresją pozorną budzi sytuacja, w której napotykamy wysokie wartości statystyk $\mathrm{t}$ równań zawierających zmienne niestacjonarne wskazujące na istotność parametrów, skojarzone z niską wartością statystyki DW. Proponuje się wręcz regułę praktyczną, zgodnie z którą gdy wartość współczynnika determinacji przekracza wartość DW, należy podejrzewać, że regresja jest pozorna. Można jednocześnie wskazać sytuację, gdy zmienne niestacjonarne „błądzą wspólnie” w tym sensie, że różnica między nimi jest stacjonarna. Innymi słowy, choć w każdej z nich występuje trend, to są one skorelowane tak, że nie rozbiegną się w czasie. O takich zmiennych mówimy, że są skointegrowane. Co ważne, regresja pomiędzy takimi zmiennymi ma już sens, a jeśli reszty są stacjonarne, to znaczy, że zmienne współewoluują w taki sposób, że różnica między nimi pozostaje stacjonarna. 

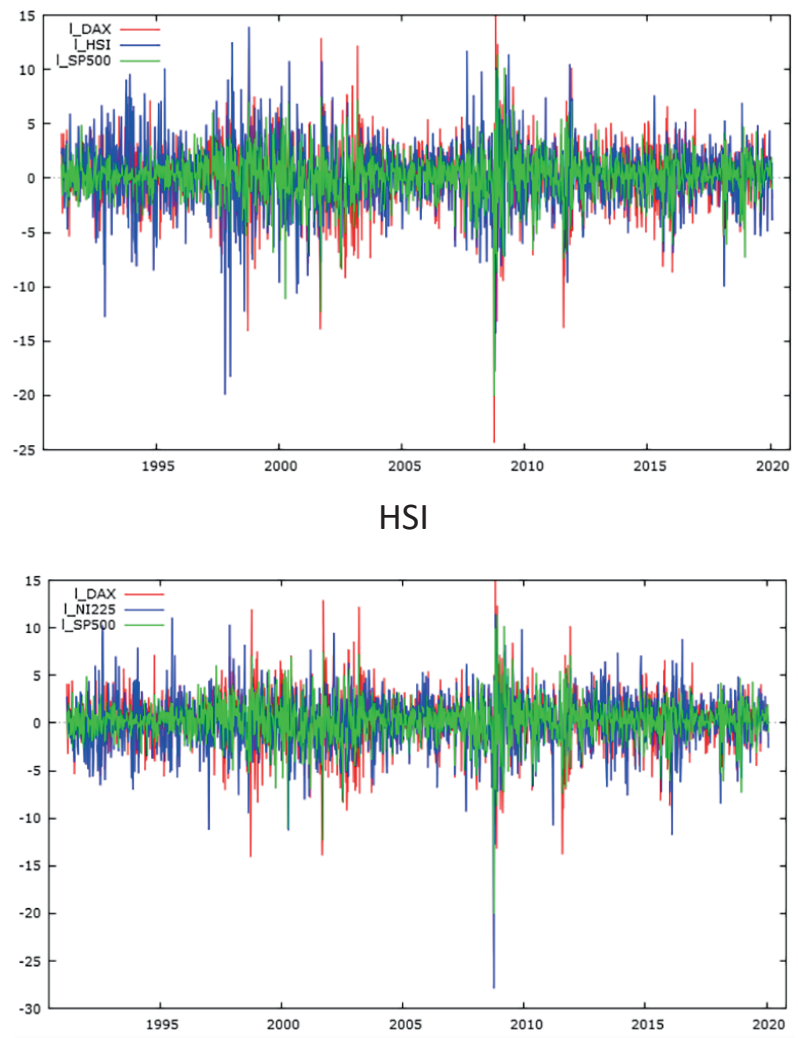

NI225

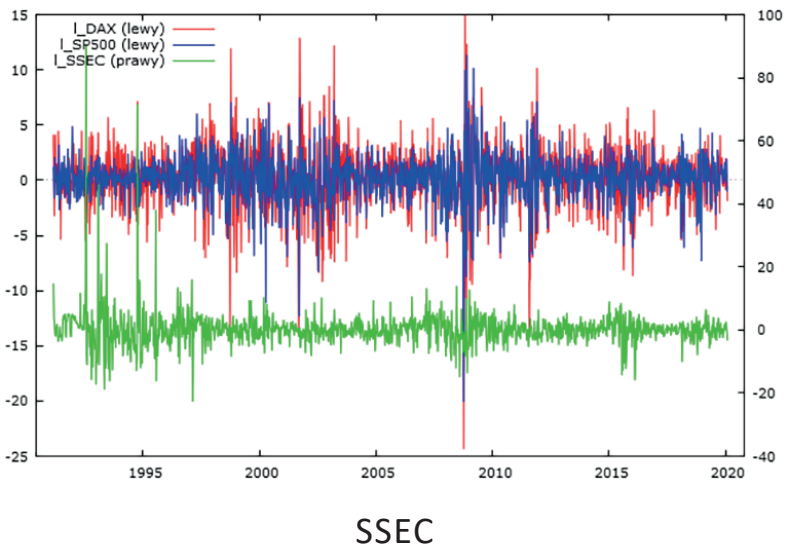

Rysunek 2. Wykres logarytmicznych stóp zwrotu dla indeksów Nikkei 225, DAX i S\&P500 w okresie 25.02.1991-27.01.2020

Źródło: opracowanie własne na podstawie danych z http://www.stooq.pl (dostęp: 15.04.2020). 
Ze względu na specyfikę badanych procesów należy zatem zweryfikować, z którą z opisanych sytuacji mamy do czynienia. Odróżnianie regresji pozornej (w której nie ma kointegracji zmiennych) od sensownej regresji wyrażającej związek długofalowy (w której zmiennej są skointegrowane) jest bowiem istotne ze względu na cel badania. W pierwszym etapie analizy zastosowano więc metodę MNK dla pierwotnych szeregów cen zamknięcia, jak również stóp zwrotu. Wyniki dotyczące MNK-estymatorów wraz z oceną istotności dla modeli cen (wariant A) oraz stóp zwrotu (wariant B) przedstawiono poniżej.

\begin{tabular}{|c|c|c|c|c|c|}
\hline & Współczynnik & Bład stand. & t-Studenta & wartość $p$ & \\
\hline Const & 5161,53 & 163,645 & 31,54 & $<0,0001$ & $\star \star \star$ \\
\hline $\mathrm{DAX}$ & 2,65172 & 0,0949948 & 27,91 & $<0,0001$ & $\star \star \star$ \\
\hline SP 500 & $-3,64202$ & 0,469458 & $-7,758$ & $<0,0001$ & $\star \star \star$ \\
\hline Wsp. determ & cat & sta & Durbina-Wa & na & 55648 \\
\hline
\end{tabular}

Model 1A. Estymacja KMNK, wykorzystane obserwacje 25.02.1991:27.01.2020 ( $\mathrm{N}=1510$ ), zmienna zależna (Y): HSI

\begin{tabular}{|c|c|c|c|c|c|}
\hline Const & Współczynnik & Bład stand. & t-studenta & wartość p & $\star \star \star$ \\
\hline DAX & $-0,601043$ & 0,146808 & $\begin{array}{r}34,27 \\
-4,094\end{array}$ & $\begin{array}{l}<0,0001 \\
<0,0001\end{array}$ & $\star \star \star \star$ \\
\hline SP 500 & 4,27716 & 0,725515 & 5,895 & $<0,0001$ & $\star \star \star$ \\
\hline
\end{tabular}

Model 2A. Estymacja KMNK, wykorzystane obserwacje 25.02.1991:27.01.2020 ( $\mathrm{N}=1510)$, zmienna zależna (Y): NI225

$\begin{array}{lcccc} & \text { Współczynnik } & \text { Bład stand. } & \text { t-Studenta } & \text { wartośćp } \\ \text { Const } & 627,790 & 36,2175 & 17,33 & <0,0001 \\ \text { DAX } & 0,551348 & 0,0210240 & 26,22 & <0,0001 \\ \text { SP500 } & -1,54268 & 0,103899 & -14,85 & <0,0001 \\ \text { Wsp. determ. R-kwadrat } \quad 0,645314 & \text { Stat. Durbina-Watsona } & 0,032558\end{array}$

Model 3A. Estymacja KMNK, wykorzystane obserwacje 25.02.1991:27.01.2020 ( $\mathrm{N}=1510)$, zmienna zależna (Y): SSEC

$\begin{array}{lcccc} & \text { Współczynnik } & \text { Błąd stand. } & \text { t-Studenta } & \text { wartość p } \\ \text { Const } & 0,144232 & 0,0840914 & 1,715 & 0,0865 \\ \text { r_DAX } & 0,0408882 & 0,0415261 & 0,9846 & 0,3250 \\ \text { r_SP500 } & -0,0828076 & 0,0552890 & -1,498 & 0,1344\end{array}$

Model 1B. Estymacja KMNK, wykorzystane obserwacje 25.02.1991:27.01.2020 ( $\mathrm{N}=1509$ ), zmienna zależna (Y): r_HSI

\begin{tabular}{|c|c|c|c|c|c|}
\hline Const & $\begin{array}{c}\text { Współczynnik } \\
-0,101547\end{array}$ & $\begin{array}{c}\text { Błąd stand. } \\
0,0644602\end{array}$ & $\begin{array}{c}\bar{t}-\text { Studenta } \\
-1,575\end{array}$ & $\begin{array}{c}\text { wartość } p \\
0,1154\end{array}$ & \\
\hline$r$ DAX & 0,293441 & 0,0318318 & 9,218 & $<0,0001$ & $\star \star \star$ \\
\hline r-SP500 & 0,360601 & 0,0423818 & 8,508 & $<0,0001$ & $\star \star \star$ \\
\hline
\end{tabular}

Model 2B. Estymacja KMNK, wykorzystane obserwacje 25.02.1991:27.01.2020 ( $\mathrm{N}=1509$ ), zmienna zależna (Y): r_NI225 


$\begin{array}{lcccc} & \text { Współczynnik } & \text { Błąd stand. } & \text { t-Studenta } & \text { wartość p } \\ \text { Const } & 0,203087 & 0,136192 & 1,491 & 0,1361 \\ \text { r_DAX } & -0,0162754 & 0,0672546 & -0,2420 & 0,8088 \\ \text { r_SP500 } & 0,126974 & 0,0895448 & 1,418 & 0,1564\end{array}$

Model 3B. Estymacja KMNK, wykorzystane obserwacje 25.02.1991:27.01.2020 ( $\mathrm{N}=1509)$, zmienna zależna (Y): r_SSEC

Zaprezentowane wyniki estymacji MNK w zakresie istotności parametrów wskazują jednoznacznie niewystępowanie krótkookresowych związków w przypadku indeksów giełdowych SSEC oraz HSI, natomiast w przypadku giełdy japońskiej związki o charakterze krótkookresowym są istotne. Ponadto istotność parametrów w modelach cen i ich brak w modelach na przyrostach jednoznacznie wskazują na podejrzenie istnienia korelacji pozornej, niemniej jednak konieczna jest weryfikacja kointegracji analizowanych procesów w celu ustalenia, czy w związku z tym korelacja ma sens, czy też nie.

W celu potwierdzenia „wspólnego błądzenia” procesów, czyli ich długofalowego związku, należy zbadać nie tylko stacjonarność procesów, ale przede wszystkim ich różnicy. W tym celu przeprowadzono test Dickeya-Fullera istnienia pierwiastka jednostkowego i ustalono stopień integracji samych procesów (tabela 1) oraz ich różnicy (tabela 2).

Tabela 1. Wartość p testu ADF dla poziomów i przyrostów zmiennych

\begin{tabular}{|l|c|c|c|c|c|}
\hline $\begin{array}{c}\text { Wartość p testu ADF } \\
\text { zmiennych }\end{array}$ & HSI & NI225 & SSEC & DAX & SP500 \\
\hline poziomy zmiennych & 0,8175 & 0,4003 & 0,3276 & 0,963 & 0,9998 \\
\hline przyrosty & $1,438 \mathrm{e}-040$ & $5,429 \mathrm{e}-011$ & $9,771 \mathrm{e}-011$ & $1,775 \mathrm{e}-030$ & $3,191 \mathrm{e}-033$ \\
\hline
\end{tabular}

Źródło: opracowanie własne.

Tabela 2. Wartość p testu ADF dla różnicy zmiennych

\begin{tabular}{|l|c|c|c|}
\hline $\begin{array}{c}\text { Wartość p testu ADF } \\
\text { zmiennych }\end{array}$ & HSI & NI225 & SSEC \\
\hline DAX & 0,5759 & 0,03064 & 0,9233 \\
\hline SP500 & 0,7624 & 0,2628 & 0,008949 \\
\hline
\end{tabular}

Źródło: opracowanie własne.

Analiza stopnia integracji zmiennych dała jednoznaczne wyniki dla rozważanych szeregów czasowych. Wartości testu ADF pozwalają przypuszczać, że wszystkie analizowane procesy charakteryzują się występowaniem pierwiastka jednostkowego w przypadku ich poziomów, co oznacza, że szeregi są zintegrowane $\mathrm{w}$ stopniu co najmniej jeden, a jednoczesne podstawy do 
odrzucenia hipotezy zerowej w teście ADF dla przyrostów potwierdza ich stacjonarność, a zatem analizowane procesy są I(1). Analogiczna weryfikacja różnic świadczy o tym, że w przypadku par indeksów NI225-DAX oraz SSEC-SP500 są podstawy do odrzucenia hipotezy zerowej w teście ADF, co oznacza, że różnica między nimi jest stacjonarna, czyli procesy te są skointegrowane i dążą do równowagi długookresowej. W przypadku pozostałych par kointegracja nie została potwierdzona. W przypadkach, w których weryfikacja potwierdziła istnienie kointegracji, stosuje się modele wektorowej autoregresji, tak zwany model korekty błędem, który pozwala wychwycić relację o charakterze długookresowym. W przeciwnym wypadku poprawne postępowanie $\mathrm{w}$ analizach wzajemnych relacji wymaga zastosowania modeli o opóźnieniach rozłożonych DL(p), które pozwalają wychwycić krótkookresowe związki. Wykrywanie związków długookresowych dotyczy zatem par indeksów zintegrowanych:

- NI225-DAX

- SSEC-SP500.

Natomiast wykrywanie związków krótkookresowych z wykorzystaniem modeli o opóźnieniach rozłożonych dotyczy następujących par indeksów:

- HSI-SP500 oraz HSI-DAX

- NI225-SP500

- SSEC-DAX

Analiza krótkookresowa oparta na modelach DL wymaga ustalenia stopnia opóźnienia, który ustalono na podstawie korelogramów wzajemnych poszczególnych par, co przedstawiono na następujących rysunkach 3-5.

Analiza wykresów korelogramów wzajemnych pozwoliła na ustalenie początkowego poziomu opóźnienia w modelach DL. Zaproponowaną klasę modeli dla poszczególnych par indeksów zestawiono w tabeli 3.
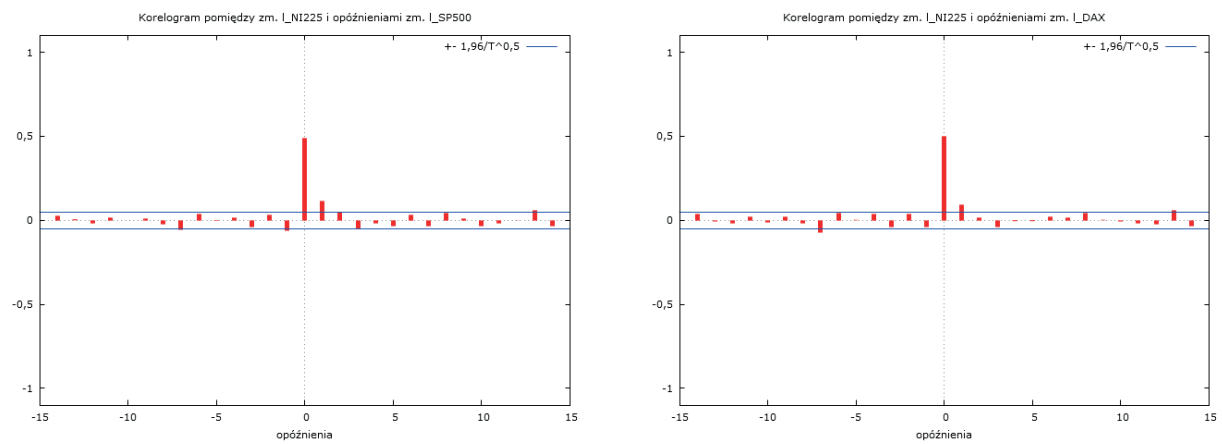

Rysunek 3. Korelogram wzajemny indeksu Hang Seng Index oraz DAX i S\&P500

Źródło: opracowanie własne. 

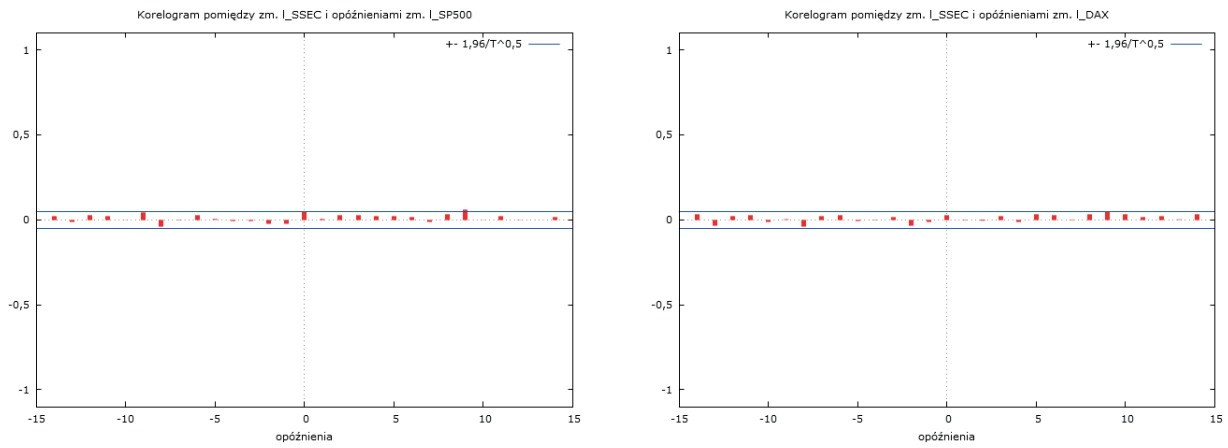

Rysunek 4. Korelogram wzajemny indeksu Nikkei 225 oraz DAX i S\&P500

Źródło: opracowanie własne.
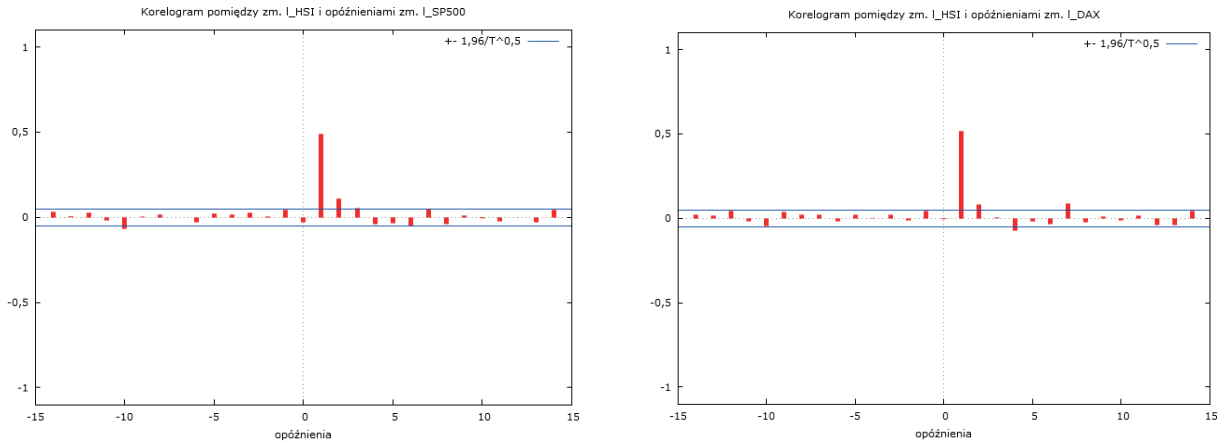

Rysunek 5. Korelogram wzajemny indeksu Shanghai Composite Index oraz DAX i S\&P500 Źródło: opracowanie własne.

Tabela 3. Wartość p testu ADF dla różnicy zmiennych

\begin{tabular}{|l|c|c|}
\hline Para zmiennych & Klasa modeli & Model \\
\hline HSI-SP500 & DL(3) & $1 \mathrm{C}$ \\
\hline HSI-DAX & DL(4) & 2C \\
\hline NI225-SP500 & DL(4) & $3 \mathrm{C}$ \\
\hline SSEC-DAX & DL(0) \\
\hline
\end{tabular}

Źródło: opracowanie własne.

Przedstawione wyniki sugerują zatem, że pomiędzy indeksem SSEC a niemieckim DAX nie obserwuje się również krótkookresowych związków, co oznaczałoby, że pomiędzy giełdą szanghajską a niemiecką (jako reprezentanta giełdy europejskiej) nie ma związków zarówno krótko-, jak i długookresowych. Dla pozostałych par wyniki MNK-estymacji parametrów modeli o opóźnieniach rozłożonych DL wraz z sekwencyjną eliminacją zmiennych nieistotnych przedstawiono poniżej. 


$\begin{array}{cccccc} & \text { Współczynnik } & \text { Bład stand. } & \text { t-Studenta } & \text { wartoś́ p } \\ \text { Const } & 5302,21 & 164,318 & 32,27 & <0,0001 \\ \text { SP500_3 } & -3,66547 & 0,460444 & -7,961 & <0,0001 \\ \text { DAX_1 } & 2,63972 & 0,0925700 & 28,52 & <0,0001 & * * * \\ \text { Wsp. determ. R-kwadrat } & 0,834473 & \text { Skorygowany R-kwadrat } & 0,834252 \\ \text { F(2, 1494) } & 3765,864 & \text { Wartość p dla testu F } & 0,000000 \\ \text { Logarytm wiarygodności } & -14019,64 & \text { Kryt. inform. Akaike'a } & 28045,28 \\ \text { Autokorel.reszt - rho1 } & 0,982826 & \text { Stat. Durbina-Watsona } & 0,32670\end{array}$

Model 1C. Estymacja KMNK, wykorzystane obserwacje 25.02.1991:27.01.2020 ( $\mathrm{N}=1497)$, zmienna zależna (Y): HSI

$\begin{array}{cccccc} & \text { Współczynnik } & \text { Błąd stand. } & \text { t-Studenta } & \text { wartość p } \\ \text { const } & 13527,2 & 247,696 & 54,61 & <0,0001 & * * * \\ \text { SP500 } & 8,61363 & 1,98657 & 4,336 & <0,0001 & * * * \\ \text { SP500_4 } & -7,09213 & 2,00500 & -3,537 & 0,0004 & * * * \\ \text { Wsp. determ. R-kwadrat } & 0,65907 & \text { Skorygowany R-kwadrat } & 0,64656 \\ \text { F(2, 1494) } & 52,70588 & \text { Wartość p dla testu F } & 7,61 e-23 \\ \text { Logarytm wiarygodności } & -14646,59 & \text { Kryt. inform. Akaike'a } & 29299,18 \\ \text { Autokorel.reszt - rhol } & 0,992260 & \text { Stat. Durbina-Watsona } & 0,11294\end{array}$

Model 2C. Estymacja KMNK, wykorzystane obserwacje 25.02.1991:27.01.2020 ( $\mathrm{N}=1497)$, zmienna zależna (Y): NI225

$\begin{array}{cccccc} & \text { Współczynnik } & \text { Bład stand. } & \text { t-Studenta } & \text { wartość p } \\ \text { const } & 456,433 & 36,4093 & 12,54 & <0,0001 & * * * \\ \text { DAX_4 } & 0,248768 & 0,00527274 & 47,18 & <0,0001 & * * * \\ \text { Wsp. determ. R-kwadrat } & 0,598222 & \text { Skorygowany R-kwadrat } & 0,597954 \\ \text { F(1, 1495) } & 2225,963 & \text { Wartość p dla testu F } & 2,5 e-298 \\ \text { Logarytm wiarygodności } & -11858,60 & \text { Kryt. inform. Akaike'a } & 23721,21 \\ \text { Kryt. bayes. Schwarza } & 23731,83 & \text { Kryt. Hannana-Quinna } & 23725,16 \\ \text { Autokorel.reszt - rho1 } & 0,988665 & \text { Stat. Durbina-Watsona } & 0,22714\end{array}$

Model 3C. Estymacja KMNK, wykorzystane obserwacje 25.02.1991:27.01.2020 ( $\mathrm{N}=1497)$, zmienna zależna (Y): SSEC

Na podstawie uzyskanych modeli otrzymano wartości mnożników, które wskazują na wzajemne relacje poszczególnych indeksów azjatyckich w stosunku do indeksu amerykańskiego i niemieckiego. Zgodnie z przedstawionymi wynikami modeli DL można stwierdzić, że rynki azjatyckie reagują z opóźnieniem w stosunku do rynku amerykańskiego czy niemieckiego, a wynika to bez wątpienia z pewnej bezwładności rynków i przystosowania się cen. Dla giełdy w Hong- kongu w modelu budzi jednak wątpliwość występowanie zarówno ujemnych, jak i dodatnich wartości parametrów. Można zatem stwierdzić, iż w krótkoterminowej perspektywie indeks HSI reaguje odwrotnie na zmiany obserwowane na giełdach europejskich w stosunku do amerykańskich, indeks DAX jest bowiem jego stymulantą, podczas gdy SP500 to destymulanta HSI. Indeks Nikkei 225 charakteryzuje się krótkookresowym związkiem tylko z rynkiem amerykańskich, co więcej, można zauważyć, że reakcja ta zależy od horyzontu czasowego. Mianowicie wzrosty giełdy amery- 
kańskiej skutkują wzrostem na giełdzie japońskiej, ale tylko w tygodniowym oknie czasowym, natomiast w skali miesiąca ta reakcja jest odwrotna. Indeks SSEC bez wątpienia naśladuje indeks niemiecki, wyniki estymacji świadczą o tym, że indeks reaguje podobnie, ale w opóźnieniu miesięcznym.

Natomiast dla par indeksów zintegrowanych, czyli NI225-DAX oraz SSEC-SP500, w celu zbadania długookresowych związków wynikających ze wspólnego błądzenia procesów kolejny etap analizy obejmuje estymację parametrów równania kointegrującego, opartą na procedurze Engla-Grangera (Lutkepohl, 2015, 352). Wyniki estymacji parametrów równania kointegrującego po korekcie specyfikacji dla wskazanych indeksów przedstawiono poniżej.

\begin{tabular}{|c|c|c|c|c|c|c|c|c|}
\hline \multicolumn{9}{|c|}{ Równanie 1: d NI225 } \\
\hline & \multicolumn{2}{|c|}{ Współczynnik } & Bład: & $\operatorname{stan} \bar{d}$ & t-Studenta & wart & ś́ć p & \\
\hline const & \multicolumn{2}{|c|}{63,3298} & \multicolumn{2}{|c|}{27,8237} & 2,276 & \multicolumn{2}{|c|}{0,0230} & $\star \star$ \\
\hline d_NI225_1 & \multicolumn{2}{|c|}{$-0,0888611$} & \multicolumn{2}{|c|}{0,0289052} & $-3,074$ & \multicolumn{2}{|c|}{0,0021} & $\star \star \star$ \\
\hline d_DAX_1 & \multicolumn{2}{|c|}{0,383682} & \multicolumn{2}{|c|}{0,0701837} & 5,467 & \multicolumn{2}{|c|}{$<0,0001$} & $\star \star \star$ \\
\hline $\mathrm{EC} 1$ & \multicolumn{2}{|c|}{$-0,00642793$} & \multicolumn{2}{|c|}{0,00240148} & $-2,677$ & \multicolumn{2}{|c|}{0,0075} & $\star \star \star$ \\
\hline \multicolumn{2}{|c|}{ Średn.aryt.zm.zależnej } & \multicolumn{2}{|c|}{$-1,545378$} & \multicolumn{3}{|c|}{ Odch.stand.zm.zależnej } & \multicolumn{2}{|c|}{441,8282} \\
\hline Suma kwadrat & eszt & \multicolumn{2}{|c|}{$2,85 e+08$} & \multicolumn{3}{|c|}{ Bład standardowy reszt } & \multicolumn{2}{|c|}{436,8500} \\
\hline \multicolumn{2}{|c|}{ Wsp. determ. R-kwadrat } & \multicolumn{2}{|c|}{0,024368} & \multicolumn{3}{|c|}{ Skorygowany R-kwadrat } & \multicolumn{2}{|c|}{0,022408} \\
\hline Autokorel.res: & rhol & \multicolumn{2}{|c|}{0,001091} & \multicolumn{3}{|c|}{ Stat. Durbina-Watsona } & \multicolumn{2}{|c|}{1,996086} \\
\hline \multicolumn{9}{|c|}{ Równanie 2: d_SSEC } \\
\hline & \multicolumn{2}{|c|}{ Współczynnik } & \multicolumn{2}{|c|}{ Błąd stand. } & t-Student & \multicolumn{2}{|c|}{ wartość p } & \\
\hline const & \multicolumn{2}{|c|}{2,74000} & \multicolumn{2}{|c|}{2,30314} & 1,190 & \multicolumn{2}{|c|}{0,2344} & \\
\hline d_sP500_1 & 0,08 & 64383 & 0,025 & 57690 & 3,354 & & 008 & $\star \star \star$ \\
\hline $\mathrm{EC} 1$ & $-0,00$ & 885949 & 0,002 & 289402 & $-3,061$ & & 022 & $\star \star \star$ \\
\hline Średn.aryt.zm & Leżnej & 1,9047 & 716 & Odch & . stand.zm.za & $z ̇ n e j$ & 88, & 870 \\
\hline Suma kwadrat & eszt & 115367 & 771 & Błąd & standardowy & reszt & 87, & 473 \\
\hline Wsp. determ. I & vadrat & 0,0133 & 351 & Skor & cygowany R-kh & drat & 0,0 & 368 \\
\hline Autokorel.res & rho1 & $-0,0035$ & & Stat & $\therefore$ Durbina-Wa & sona & 2,0 & 5885 \\
\hline
\end{tabular}

System VECM (wektorowy model korekty błędem), rząd opóźnienia 4. Estymacja największa wiarygodność dla obserwacji 25.02.1991:27.01.2020 ( $\mathrm{T}=1497)$

Kointegracja występuje, gdy proces resztowy z równania kointegrującego jest procesem stacjonarnym, czyli I(0), to znaczy hipoteza zerowa o pierwiastku jednostkowym, jest odrzucana dla reszt modelu. Dlatego też w kolejnym etapie zbadano stacjonarność reszt równania kointegrującego, wykorzystując ponownie test ADF. Wartości p testu ADF dla reszt przedstawiono w tabeli 4.

Tabela 4. Wartość p testu ADF reszt równania kointegrującego

\begin{tabular}{|c|c|}
\hline Równanie & Wartość $\mathrm{p}$ \\
\hline równanie 1: d_NI225 & $1,094 \mathrm{e}-012$ \\
\hline równanie 2: d_SSEC & $3,778 \mathrm{e}-010$ \\
\hline
\end{tabular}

Źródło: opracowanie własne.

Ekonomia - Wroclaw Economic Review 26/1, 2020

(C) for this edition by CNS 
Mała wartość $\mathrm{p}$ zaobserwowana w przypadku procesu resztowego modelu VECM oznacza podstawy do odrzucenia hipotezy zerowej, reszty z równania kointegrującego są zatem stacjonarne. Występuje więć kointegracja między szeregami indeksów analizowanych giełd azjatyckich NI225 oraz SSEC i wskazanych indeksów DAX i SP500. Przeprowadzona analiza kointegracji metodą Engle'a-Grangera wykazała, że występują zależności długookresowe między indeksami, a uzyskane estymatory parametrów świadczą o tym, że ostatnio zrealizowany przyrost wartości indeksu DAX ma wpływ na bieżący wzrost indeksu NI225, który wynosi 0,38 punktu procentowego, natomiast w przypadku indeksu SSEC wpływ indeksu SP500 jest zdecydowanie niższy i wynosi zaledwie 0,09 punktu procentowego. Ujemna wartość parametru EC1 zapewnia natomiast dochodzenie do stanu równowagi w przypadku obu par indeksów, a jego wartości oznaczają, że zaledwie około 0,6\% zmian wartości indeksu NI225 od długookresowej zależności z DAX jest redukowana w ciągu jednego tygodnia, w przypadku indeksu SSEC redukcja dotyczy zaś około $0,8 \%$ odchyleń indeksu od stanu równowagi.

\section{Wnioski}

Przeprowadzone badania empiryczne pozwoliły na określenie, w jakim stopniu rynek amerykański oraz europejski wpływają na rynki azjatyckie oraz jaki charakter mają relacje między tymi giełdami. Badania empiryczne dotyczące krótkookresowego wpływu giełd europejskich i amerykańskich wykazały, że rynek amerykański w krótkiej perspektywie ma największy wpływ na rynek japoński, zmiany zaś na rynku niemieckim wpływają w największym stopniu na rynek w Hongkongu. Należy jednak podkreślić, że procesami skointegrowanymi okazały się tylko pary indeksów NI225-DAX oraz SSEC-SP500, co oznacza, że charakteryzują się one wspólną istotną długookresową zależnością i w obu przypadkach uzyskane wyniki potwierdziły zbieżność do stanu równowagi.

\section{Bibliografia}

Analiza Szeregów Czasowych (2009). Data dostępu: 15.04.2020, http://www.cs.put.poznan.pl/jstefanowski/aed/TPtimeseries.pdf.

Dane historyczne: Nikkei 225 - Japan $\left({ }^{\wedge} N K X\right)$. Data dostępu: 15.04.2020, https://stooq.pl/q/d/?s= \%5Enkx\&c=0\&d1=19890101\&d2=19900114.

Dane historyczne: Shanghai Composite Index - China (^SHC). Data dostępu: 15.04.2020, https:// stooq.pl/q/d/? $=\% 5$ Eshc $\& \mathrm{c}=0 \& \mathrm{i}=\mathrm{w}$.

Dane historyczne: Shanghai Composite Index - China (^SHC). Data dostępu: 15.04.2020, https:// stooq.pl/q/d/?s=\%5Eshc\& $=0 \& d 1=19901219 \& d 2=20200225 \& \mathrm{i}=\mathrm{w}$.

Domańska-Szaruga, B. (2009). Globalizacja rynków finansowych. Zeszyty Naukowe, Seria: Administracja i Zarzadzanie, 80.

Giełda w Chinach (26.02.2019). Data dostępu: 15.04.2020, https://pchig.pl/blog/gielda-w-chinach/.

Ekonomia - Wroclaw Economic Review 26/1, 2020

(C) for this edition by CNS 
HKEX Fact Book 2018, Data dostępu: 15.04.2020, https://www.hkex.com.hk/-/media/HKEX-Market/Market-Data/Statistics/Consolidated-Reports/HKEX-Fact-Book/HKEX-Fact-Book-2018/ FB_2018.pdf?la=en].

Hong Kong Stock Exchange. Data dostępu: 15.05.2020, http://tradersarea.pl/hong-kong-stock-exchange/.

Index Methodology For Managing the Hang Seng Index. Data dostępu: 15.04.2020, https://www. hsi.com.hk/static/uploads/contents/en/dl_centre/methodologies/IM_hsie.pdf.

Lasoń, M. (red.) (2010). Między kryzysem, a wspótpraca. Kraków: Krakowska Akademia im. Andrzeja Frycza Modrzewskiego.

Lista komponentów indeksu $\wedge^{\wedge} N K X$. Data dostępu: 15.04.2020, https://stooq.pl/q/i/? $\mathrm{s}={ }^{\wedge} \mathrm{nkx}$.

Lutkepohl, H. (2015). New Introduction to Multiple Time Series Analysis. Berlin: Springer-Verlag.

Notowania ${ }^{\wedge}$ HSI (Hong Kong). Data dostępu: 15.04.2020, https://www.biznesradar.pl/notowania/ HSI-HANG-SENG\#max lin lin.

Prenzena, P. (2016), Analiza powiązań między indeksami giełdy francuskiej, holenderskiej i belgijskiej z wykorzystaniem modelu korekty błędem, Studia Ekonomiczne. Zeszyty Naukowe Uniwersytetu Ekonomicznego w Katowicach, 289, 111.

Przekota, G. (2007), Analiza zależności między indeksami rynków akcji na giełdzie polskiej i amerykańskiej. Badania Operacyjne i Decyzje, 3-4.

Rosik, P. (19.02.2019). Bank Japonii rozkręcit hossę na giełdzie w Tokio. Data dostępu: 15.04.2020, https://strefainwestorow.pl/artykuly/badania/20190219/bank-japonii-rozkrecil-hosse-na-gieldzie-w-tokio].

Ryzyko rynkowe. Data dostępu: 15.04.2020, https://www.edukacjagieldowa.pl/gieldowe-abc/psychologia-inwestowania/ryzyko-rynkowe/.

Schittek, D. (10.04.2014). Analiza indeksów giełdowych: SSE Composite (Chiny) - 10.04.2014. Data dostępu: 15.04.2020 https://analizy.investio.pl/analiza-indeksow-gieldowych-sse-composite-chiny-10-04-2014/.

Shanghai Stock Exchange. Data dostępu: 15.04.2020, http://tradersarea.pl/shanghai-stock-exchange/].

Ekonomia - Wroclaw Economic Review 26/1, 2020

(C) for this edition by CNS 